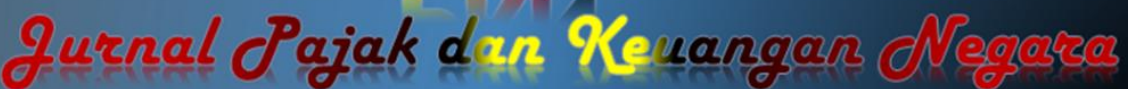

\section{PENGARUH DESENTRALISASI FISKAL, INVESTASI, DAN INDEKS PEMBANGUNAN MANUSIA TERHADAP PERTUMBUHAN EKONOMI REGIONAL DI PROVINSI KALIMANTAN TIMUR}

\author{
Agung Dinarjito \\ Politeknik Keuangan Negara STAN \\ Almizar Dharmazi \\ Badan Pendidikan dan Pelatihan Keuangan
}

Alamat Korespondensi: agung.dinarjito@pknstan.ac.id

INFORMASI ARTIKEL

Diterima Pertama

[19 Maret 2020]

Dinyatakan Diterima

[20 Maret 2020]

\section{KATA KUNCI:}

desentralisasi fiskal, indek pembangunan manusia, investasi, pertumbuhan ekonomi

KLASIFIKASI JEL:

O23, R12

\section{ABSTRAK}

Economic growth can be influenced by several factors, including fiscal decentralization, government investment, and also the level of human development. Therefore, this study aims to analyze the effect of fiscal decentralization, investment and human development index on regional economic growth in the province of East Kalimantan. East Kalimantan Province is one of the biggest mining producers in Indonesia, but the economic growth is negative. This research is a quantitative descriptive study using linear regression analysis method. The conclusion from this study is that only the human development index significantly influences regional economic growth in East Kalimantan Province. The author hopes that this research will be able to encourage Local Governments to evaluate existing policies by focusing on human development, increasing the effectiveness of Government investment and overseeing the implementation of fiscal decentralization.

Pertumbuhan ekonomi dapat dipengaruhi oleh beberapa faktor, antara lain desentralisasi fiskal, investasi pemerintah, dan juga tingkat pembangunan manusianya. oleh karena itu, penelitian ini bertujuan untuk menganalisisi pengaruh desentralisasi fiskal, investasi dan indeks pembangunan manusia terhadap pertumbuhan ekonomi regional di Provinsi Kalimantan Timur. Provinsi Kalimantan Timur merupakan salah satu penghasil tambang terbesar di Indonesia, namun pertumbuhan ekonominya secara rata-rata negatif. Penelitian ini merupakan penelitian kuantitatif deskriptif dengan menggunakan metode analisis regresi linier. Simpulan dari penelitian ini adalah bahwa hanya indeks pembangunan manusia yang secara signfikan mempengaruhi pertumbuhan ekonomi regional di Provinsi Kalimantan Timur. Penulis berharap agar penelitian ini mampu mendorong Pemerintah Daerah mengevaluasi kebijakan yang ada dengan memfokuskan pada pembangunan manusia, meningkatkan efektivitas investasi Pemerintah dan pengawasan pelaksanaan desentralisasi fiskal. 


\section{PENDAHULUAN}

Pertumbuhan Ekonomi merupakan suatu ukuran yang menunjukkan adanya perkembangan dan peningkatan perekonomian suatu wilayah dibandingkan dengan tahun sebelumnya. Menurut Meier (1989), pertumbuhan ekonomi dan pembangunan ekonomi memiliki keterkaitan hubungan yang erat, dimana pertumbuhan ekonomi merupakan syarat utama dari beberapa syarat yang dibutuhkan dalam proses pembangunan. Pertumbuhan ekonomi sebagai sebuah proses peningkatan output dari waktu ke waktu, menjadi indikator penting dalam mengukur keberhasilan pembangunan suatu negara (Todaro, 2005).

Dalam konteks otonomi daerah, salah satu faktor yang berpengaruh terhadap pertumbuhan ekonomi daerah adalah desentralisasi fiskal. Sebagian besar ekonom percaya bahwa desentralisasi fiskal dapat mendorong pertumbuhan ekonomi, memperbaiki pemerataan, dan meningkatkan kualitas pelayanan publik serta kesejahteraan masyarakat dan sebagian lain berpandangan sebaliknya (Saputra \& Mahmudi, 2012). Penelitian Amagoh \& Ajab Amin (2012) menyatakan bahwa desentralisasi fiskal yang efektif dipengaruhi oleh kerangka kelembagaan yang bersifat komprehensif sehingga kebijakan desentralisasi fiskal menghasilkan manfaat tambahan bagi akuntabilitas, pendapatan, dan otonomi politik serta meningkatkan kualitas pelayanan publik. Penelitian tersebut menyimpulkan bahwa dalam literatur teoritis lebih condong mendukung hubungan positif antara desentralisasi fiskal dan pertumbuhan ekonomi.

Oates (1993), Bird (1993) dan Bahl, R. W. \& Linh (1992) menyatakan bahwa dengan adanya kewenangan desentralisasi fiskal diharapkan layanan kepada masyarakat akan semakin efisien dan ujungnya akan mendorong pertumbuhan ekonomi. Selain itu, penelitian Zhang, T., \& Zou (2001) juga menunjukkan bahwa desentralisasi memiliki pengaruh positif terhadap pertumbuhan ekonomi di India. Oates (1993) berpendapat bahwa desentralisasi dipandang sebagai suatu langkah untuk meningkatkan efisiensi pemerintahan, mengurangi defisit anggaran dan meningkatkan laju pertumbuhan ekonomi.

Namun sebaliknya, Martinez \& McNab (2001) dan World Bank (1997) menyatakan bahwa desentralisasi fiskal juga berdampak negatif terhadap pertumbuhan ekonomi. Desentralisasi fiskal dapat mendorong ke arah ketidakstabilan ekonomi makro yang pada gilirannya akan menghambat pertumbuhan ekonomi. Hal yang sama juga ditegaskan dalam penelitian Phillips \& Woller (1997) dan Davoodi \& Zou (1998) bahwa adanya pengaruh negatif desentralisasi fiskal terhadap pertumbuhan ekonomi dalam kasus di negara-negara berkembang. Hal ini juga konsisten dengan penelitian di Indonesia oleh Jumadi, Maski, \& Khusaini (2013) dan Saputra \& Mahmudi (2012) yang menunjukkan pengaruh ke arah negatif.
Dalam pelaksanaan desentralisasi fiskal, pemerintah daerah melakukan pengeluaran atau belanja daerah. Sangat penting bagi pemerintah daerah dalam menggunakan sumber daya yang dimilikinya sehingga mampu mendorong kegiatan ekonomi dan meningkatkan pertumbuhan ekonomi melalui peningkatan Produk Domestik Regional Bruto (PDRB).

Faktor lain yang dapat memengaruhi pertumbuhan ekonomi adalah investasi pemerintah. Selain dilakukan sebagai bentuk pelayanan kepada masyarakat, investasi pemerintah juga memiliki kontribusi terhadap pertumbuhan ekonomi. Umumnya, kegiatan investasi yang dilakukan oleh pemerintah tidak hanya untuk mencari keuntungan semata, namun juga menjadi stimulus dalam melancarkan dan meningkatkan roda perekonomian masyarakat dalam bentuk belanja modal. Dengan adanya fasilitas infrastruktur yang baik, dapat menjadi daya tarik investor lokal maupun asing untuk berinvestasi di daerahnya. Hal tersebut dapat berdampak pada peningkatan perekonomian bahkan penciptaan lapangan kerja baru bagi masyarakat.

Dalam penelitian yang dilakukan oleh Dwirandra (2013) memperoleh kesimpulan bahwa keserasian belanja modal berpengaruh positif terhadap pertumbuhan ekonomi. Hal tersebut konsisten dengan penelitian Situngkir, Sirojuzilam, \& Suriadi (2014) dan Jumadi, M. Pudjiharjo (2013) yang memperoleh hasil yang sama. Saragih (2003) menyatakan bahwa apabila Pemerintah Daerah menetapkan belanja modal lebih besar dari pengeluaran rutin, maka kebijakan ekspansi anggaran daerah akan mendongkrak pertumbuhan ekonomi daerah. Lin \& Liu (2000) dalam penelitiannya mengatakan bahwa pemerintah perlu meningkatkan investasi modal guna meningkatkan pertumbuhan ekonomi daerah. Namun, hasil penelitian yang berbeda ditemukan dalam penelitian Sulistiawati (2012) yang menyatakan bahwa investasi pemerintah justru berpengaruh negatif dan tidak signifikan terhadap pertumbuhan ekonomi. Begitu pula dengan Bado (2015) dan Bati (2009) yang menyatakan bahwa investasi atau belanja modal tidak berpengaruh secara signifikan terhadap pertumbuhan ekonomi.

Kesejahteraan masyarakat sebagai tujuan dari pelaksanaan otonomi daerah menjadi hal yang sangat penting untuk diperhatikan oleh pemerintah daerah. Tidak hanya berfokus pada kuantitas penyediaan layanan dasar saja, namun peningkatan kualitas layanan juga turut harus dijamin oleh pemerintah daerah. Fasilitas pendidikan dan kesehatan yang baik merupakan hal yang sangat penting untuk disediakan oleh Pemerintah Daerah demi menciptakan sumber daya manusia yang berkualitas dan produktif. Pembangunan manusia tersebut akan menciptakan modal manusia (human capital) yang bernilai. Dengan segala pengetahuan, inovasi dan kreativitas yang dimilikinya, dapat dimanfaatkan oleh pemerintah 
daerah untuk mengembangkan kapasitas daerah dengan memanfaatkan teknologi modern yang ada agar terciptanya pertumbuhan serta pembangunan yang berkelanjutan (Todaro, Michael P. \& Smith, 2006).

Penelitian yang dilakukan oleh Jumadi et al. (2013) memperoleh hasil yang menunjukkan adanya pengaruh positif dan signifikan pembangunan manusia terhadap pertumbuhan ekonomi. Sejalan dengan penelitian Situngkir et al. (2014) dan Nurmainah (2013) yang juga memperoleh temuan bahwa indeks pembangunan manusia secara signifikan berpengaruh positif terhadap pertumbuhan ekonomi. Berbeda halnya dengan penelitian Muqorrobin \& Soejoto (2017) yang memperoleh hasil yang berkebalikan bahwa indeks pembangunan manusia berpengaruh negatif dan signifikan terhadap pertumbuhan ekonomi.
Desentralisasi fiskal, investasi dan human capital menjadi suatu hal yang penting dalam menciptakan pertumbuhan ekonomi suatu daerah. Dalam teori pertumbuhan ekonomi klasik, pertumbuhan ekonomi bergantung pada faktor-faktor produksi yang terdiri dari tiga unsur pokok antara lain ketersediaan sumber daya alam, ketersediaan sumber daya insani dan stok modal (Sukirno, 2011). Ketiga unsur pokok tersebut mewakili beberapa unsur yang dimiliki daerah.

Provinsi Kalimantan Timur (Kaltim) merupakan salah satu provinsi yang dikenal sebagai penghasil tambang terbesar di Indonesia. Jenis produk tambang yang utama dihasilkan oleh Provinsi Kaltim antara lain minyak, gas alam dan batu bara. Ketiga hasil sumber daya alam tersebut menjadi komoditas terbesar dalam menyumbang proporsi produksi tambang nasional di Indonesia.

Gambar 1: Provinsi Penghasil Minyak Terbesar di Indonesia

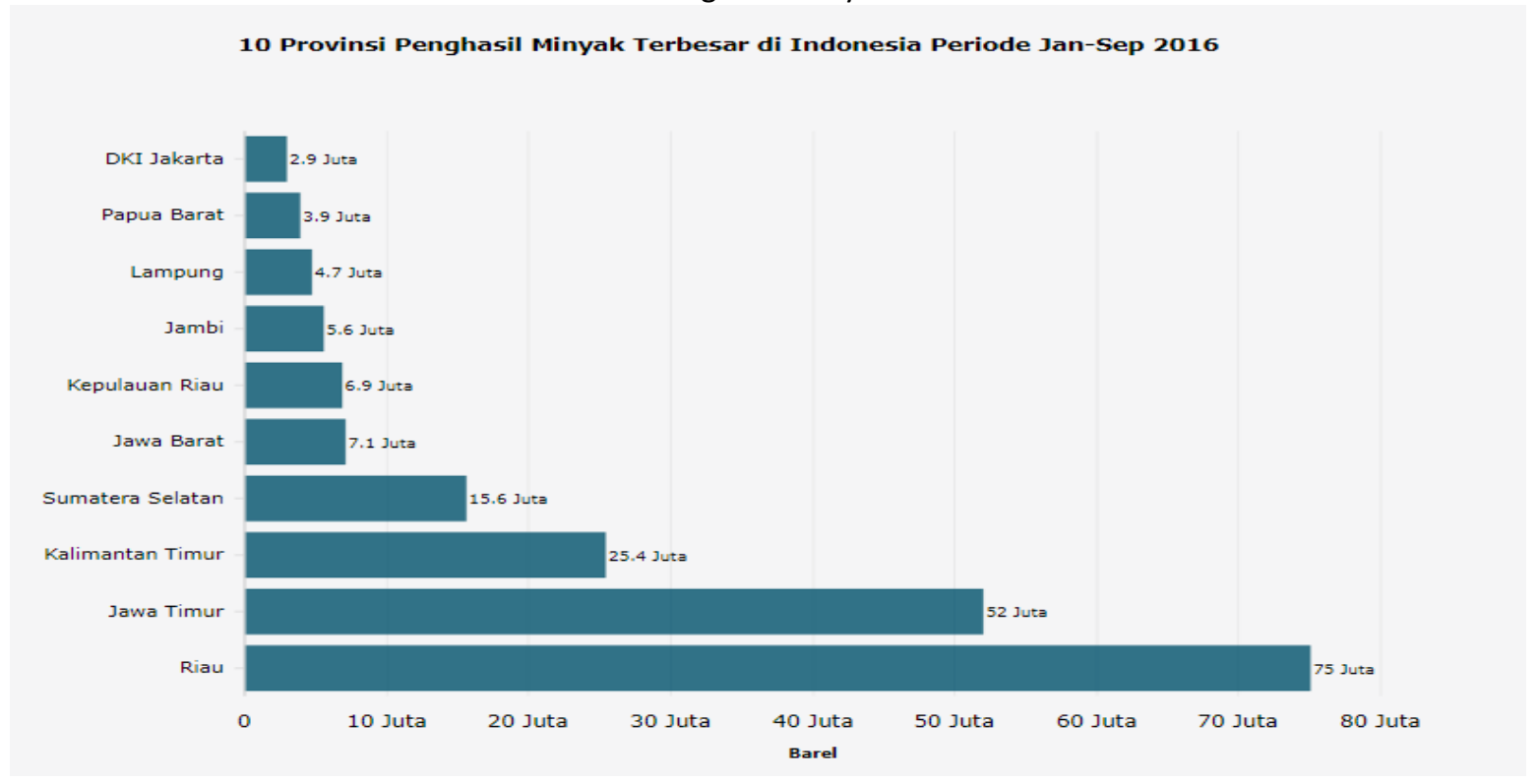

Sumber: Kata Data Indonesia

Pada Gambar 1, dapat dilihat bahwa produksi minyak Kalimantan Timur menduduki posisi ketiga sebagai penghasil minyak terbesar di Indonesia setelah Provinsi Riau dan Jawa Timur. Selain itu, Provinsi Kalimantan Timur juga menjadi salah satu penghasil gas alam dan batu bara terbesar di Indonesia, bahkan menduduki peringkat pertama (gambar terlampir). Dengan kekayaan sumber daya alam melimpah yang dimilikinya, tak heran jika Provinsi Kalimantan Timur memiliki pendapatan daerah yang besar yang digunakan untuk pembangunan daerahnya. Pendapatan daerah yang berasal dari bagian hasil pertambangan diharapkan dapat digunakan untuk meningkatkan belanja Pemerintah Daerah yang hasil akhirnya adalah mendorong pertumbuhan ekonomi. Berdasarkan data di atas, dapat dikatakan bahwa provinsi Kaltim sudah memiliki kemandirian fiskal yang baik karena dapat memaksimalkan potensi pendapatan yang ada di daerahnya. Namun, capaian ini tidak diikuti dengan pertumbuhan ekonomi regional yang positif dan meningkat malah cenderung mengalami penurunan setiap tahunnya.

Pada Gambar 2, dapat dilihat bahwa pertumbuhan ekonomi regional Provinsi Kalimantan Timur cenderung mengalami penurunan bahkan menyentuh angka negatif yakni di angka -1,21 pada tahun 2015 dan -0.38 pada tahun 2016. Pada tahun 2016 tersebut, Kaltim menjadi provinsi dengan pertumbuhan ekonomi terendah dibandingkan dengan provinsi lain di Indonesia. Dari beberapa provinsi penghasil sumber daya alam di atas, hanya Provinsi Kalimantan Timur yang mengalami pertumbuhan ekonomi hingga menyentuh angka 
minus. Hal ini menunjukkan bahwa desentralisasi fiskal berdasarkan indikator kemampuan daerah belum mampu memberikan pengaruh positif terhadap pertumbuhan ekonomi. Berdasarkan hal tersebut, dalam penelitian ini, penulis tertarik untuk mengangkat suatu pertanyaan penelitian yakni "Apakah desentralisasi fiskal, investasi, dan indeks pembangunan manusia memberikan pengaruh kepada pertumbuhan ekonomi regional Provinsi Kalimantan Timur.

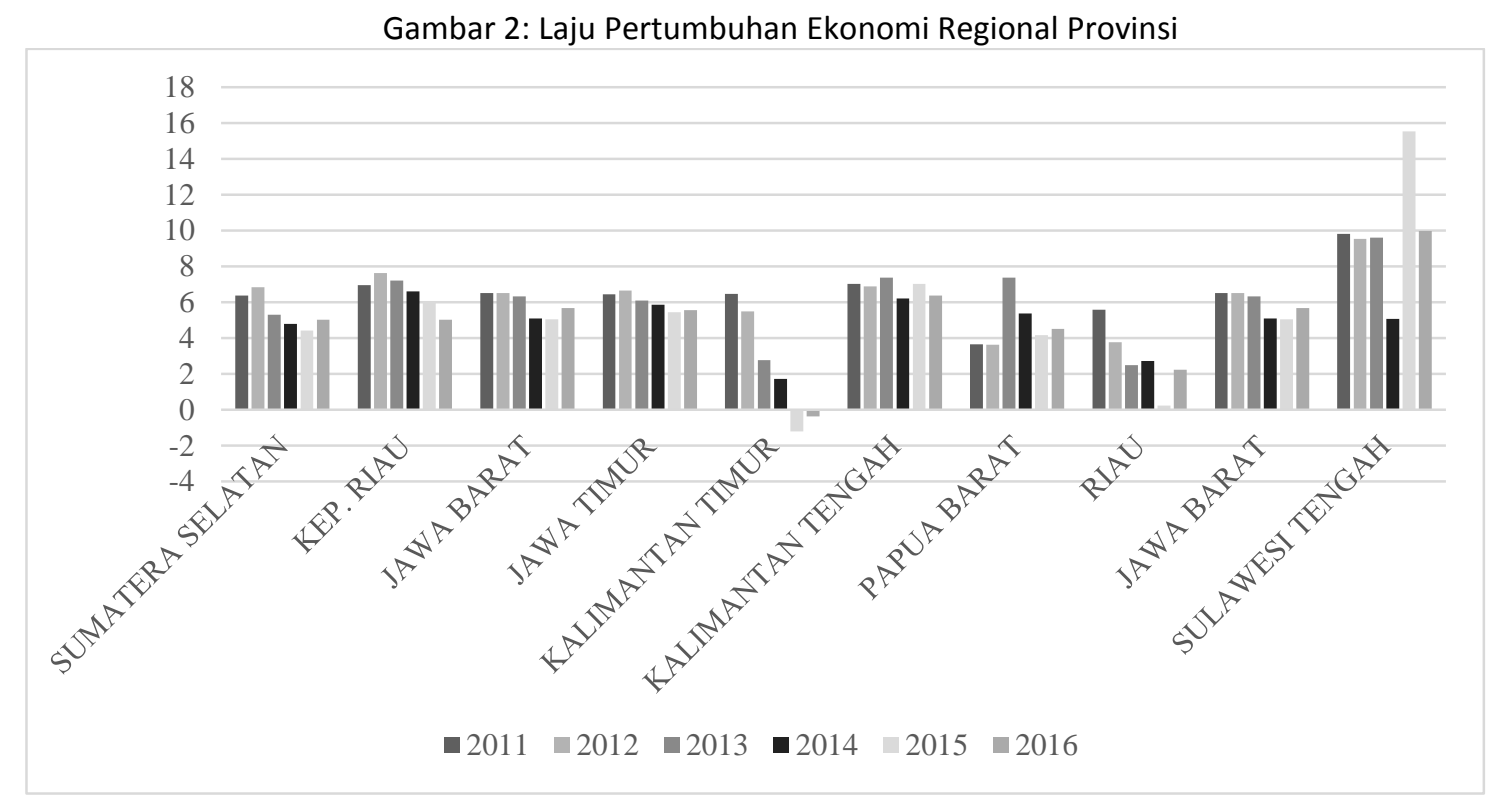

Sumber: Diolah dari Badan Pusat Statistik

\section{TINJAUAN PUSTAKA}

Menurut Smith dalam Arsyad (1999), pertumbuhan ekonomi dipengaruhi oleh dua faktor utama antara lain pertumbuhan output total dan pertumbuhan penduduk. Sukirno (2011) juga menjelaskan bahwa pertumbuhan ekonomi bergantung pada faktor-faktor produksi karena peningkatan pertumbuhan ekonomi didahului oleh peningkatan faktor produksi.

\section{a. Pengaruh Desentralisasi Fiskal Terhadap} Pertumbuhan Ekonomi

Sudah banyak penelitian yang dilakukan untuk melihat pengaruh desentralisasi fiskal terhadap pertumbuhan ekonomi. Penelitian Oates (1993), Martinez \& McNab (2001) menyatakan bahwa desentralisasi fiskal dapat mendorong efisiensi ekonomi dan secara dinamis akan mendorong pertumbuhan ekonomi suatu daerah. Mereka berargumen belanja daerah yang dihasilkan dari desentralisasi fiskal akan meningkatkan pertumbuhan ekonomi melalui berbagai belanja yang dilakukannya.

Penelitian Amagoh \& Ajab Amin (2012) menyatakan bahwa desentralisasi fiskal yang efektif akan mendukung hubungan positif antara desentralisasi fiskal dan pertumbuhan ekonomi. Sejalan dengan itu, Bird (1993) dan Bahl, R. W. \& Linh (1992) menyatakan bahwa dengan adanya kewenangan desentralisasi fiskal diharapkan layanan kepada masyarakat akan semakin efisien dan ujungnya akan mendorong pertumbuhan ekonomi.
Selain itu, penelitian Zhang, T., \& Zou (2001) juga menunjukkan bahwa desentralisasi memiliki pengaruh positif terhadap pertumbuhan ekonomi di India.

b. Pengaruh Investasi Terhadap Pertumbuhan Ekonomi

Teori neoklasik mengatakan bahwa Investasi dipandang sebagai salah satu penggerak utama pertumbuhan ekonomi dan pembangunan (Nanga, 2005). Umumnya, kegiatan investasi yang dilakukan oleh pemerintah tidak hanya untuk mencari keuntungan semata namun digunakan untuk melakukan belanja modal dalam menunjang kehidupan masyarakatnya. Dengan adanya fasilitas infrastruktur yang baik, dapat menjadi daya tarik investor lokal maupun asing untuk berinvestasi di daerahnya. Hal tersebut dapat berdampak pada peningkatan perekonomian bahkan penciptaan lapangan kerja baru bagi masyarakat.

Handayani (2011) menyatakan bahwa hubungan investasi dengan pertumbuhan ekonomi adalah dengan adanya investasi berupa pembelian barang modal yang digunakan untuk meningkatkan kemampuan memproduksi barang dan jasa yang dibutuhkan dalam perekonomian sehingga hal ini dapat meningkatkan PDB dan secara otomatis akan berpengaruh positif terhadap pertumbuhan ekonomi. Sejalan dengan hasil penelitian Handayani, Sutawijaya (2010) juga menyatakan bahwa peningkatan investasi akan meningkatkan kapasitas produksi yang pada 
akhirnya berujung pada pembukaan lapangan kerja baru, yang pada tahap selanjutnya akan mendorong pertumbuhan ekonomi.

Dalam penelitian yang dilakukan oleh Dwirandra (2013) disimpulkan bahwa keserasian belanja modal berpengaruh positif terhadap pertumbuhan ekonomi. Hal tersebut konsisten dengan penelitian Situngkir et al. (2014) dan Jumadi et al. (2013) yang memperoleh hasil yang sama. Saragih (2003) menyatakan bahwa apabila Pemerintah Daerah menetapkan belanja modal lebih besar dari pengeluaran rutin, maka kebijakan ekspansi anggaran daerah akan mendongkrak pertumbuhan ekonomi daerah. Lin \& Liu (2000) dalam penelitiannya mengatakan bahwa pemerintah perlu meningkatkan investasi modal guna meningkatkan pertumbuhan ekonomi daerah.

c. Pengaruh Indeks Pembangunan Manusia Terhadap Pertumbuhan Ekonomi

Tenaga kerja merupakan faktor yang penting dalam proses produksi dalam menghasilkan barang jasa. Produksi barang dan jasa inilah yang nanti akan mempengaruhi pertumbuhan ekonomi (Simanjuntak, 2005).

Salah satu belanja daerah yang harus dikeluarkan adalah belanja pendidikan dan belanja kesehata. Penyedian fasilitas pendidikan dan kesehatan yang baik dan memadai akan mendorong meningkatnya kualitas manusia. Peningkatan kualitas manusia tersebut akan menciptakan modal manusia (human capital) yang bernilai. Todaro, Michael P. \& Smith (2006) dalam penelitiannya menyatakan bahwa modal manusia dengan segala pengetahuan, kualitas, kreativitasnya dapat digunakan dalam meningkatkan kapasitas daerahnya agar tercipta pertumbuhan daerah. Jumadi et al. (2013), Situngkir et al. (2014) dan Nurmainah (2013) dalam penelitiannya juga menyatakan bahwa bahwa indeks pembangunan manusia secara signifikan berpengaruh positif terhadap pertumbuhan ekonomi.

\section{METODE PENELITIAN}

Penelitian ini merupakan penelitian kuantitatif yang bertujuan untuk melihat pengaruh desentralisasi fiskal, investasi, dan indeks pembangunan manusia terhadap pertumbuhan ekonomi regional Provinsi Kalimantan Timur. Dalam penelitian ini, pertumbuhan ekonomi bertindak sebagai variabel dependen, sedangkan desentralisasi fiskal, investasi, dan indeks pembangunan manusia bertindak sebagai variabel independen.

Model penelitian yang digunakan dalam pembahasan penelitian ini adalah:

Model Persamaan:

$$
\begin{gathered}
P E_{i, t}=\alpha_{0 i, t}+\beta_{1} D F_{i, t}+\beta_{2} I N V_{i, t}+\beta_{3} I P M_{i, t} \\
+\varepsilon_{i t}
\end{gathered}
$$

Keterangan:

$\begin{array}{lll}\text { PE } & : & \text { Laju Pertumbuhan Ekonomi Daerah } \\ \text { DF } & : & \text { Desentralisasi Fiskal Daerah } \\ \text { INV } & : & \text { Investasi Pemerintah } \\ \text { IPM } & : & \text { Indeks Pembangunan Manusia } \\ \alpha & : & \text { Konstanta }\end{array}$

Model di atas digunakan untuk menguji hipotesis yang dibangun penulis, yaitu:

$H_{1}=$ Desentralisasi fiskal secara signifikan berpengaruh positif terhadap pertumbuhan ekonomi. $\mathrm{H}_{2}=$ Investasi secara signifikan berpengaruh positif terhadap pertumbuhan ekonomi.

$\mathrm{H}_{3}=$ Indeks pembangunan manusia secara signifikan berpengaruh positif terhadap pertumbuhan ekonomi.

Untuk menguji hipotesis, jenis data yang digunakan dalam penelitian ini adalah data sekunder (data panel) yang diperoleh dari data publikasi di situs Direktorat Jenderal Perimbangan Keuangan dan situs Badan Pusat Statistik. Data yang digunakan adalah data Laporan Realisasi APBD Kota/Kabupaten di Provinsi Kalimantan Timur dan Data Indeks Pembangunan Manusia (IPM) selama periode 20102016. Data yang dapat diperoleh dalam Laporan Realisasi APBD terdiri dari data PAD, DBH, belanja modal, total pendapatan, dan total belanja pada masing-masing kabupaten/kota di Provinsi Kalimantan Timur.

Variabel terikat dalam penelitian ini yaitu pertumbuhan ekonomi di setiap kabupaten/kota di Provinsi Kalimantan Timur selama tahun 2010-2016. Pertumbuhan ekonomi merupakan perubahan PDRB setiap tahun berdasarkan harga konstan yang dinyatakan dalam satuan persen. Rumus pertumbuhan ekonomi:

Pertumbuhan Ekonomi

$$
=\frac{P D R B_{t}-P D R B_{(t-1)}}{P D R B_{(t-1)}} \times 100 \%
$$

Variabel bebas dalam penelitian ini antara lain:

a. Desentralisasi Fiskal (DF), dilambangkan dengan rasio angka yaitu derajat desentralisasi fiskal, yang didefinisikan sebagai tingkat kemampuan pemerintah daerah dalam menjalani otonomi daerah apabila pengeluarannya dibiayai dari PAD dan Dana Bagi Hasil. Berdasarkan Undang-Undang Nomor 33 Tahun 2004, kapasitas fiskal daerah merupakan kemampuan keuangan daerah yang sumber pendanaannya berasal dari PAD dan Dana Bagi Hasil. Sehingga desentralisasi fiskal dalam penelitian ini diproksikan dengan rasio antara Pendapatan Asli Daerah (PAD) ditambah Dana Bagi Hasil (DBH) terhadap Realisasi Total Pengeluaran kabupaten/kota (Sasana, 2006; Saputra \& Mahmudi, 2012; Zaufi et al., 2016). Rumus desentralisasi fiskal: 


\section{Desentralisasi Fiskal

$$
=\frac{P A D+D B H}{\text { Total Pengeluaran kabupaten } / \text { kota }}
$$

b. Investasi (IP) yaitu penanaman modal pemerintah yang diwakili dengan rasio antara belanja modal kabupaten/kota terhadap total belanja kabupaten/kota (Kusuma, 2016). Rumus investasi: Investasi $=\frac{\text { Belanja modal kabupaten } / \text { kota }}{\text { Total belanja kabupaten } / \text { kota }}$

c. Pembangunan Manusia (PM) yaitu mewakili kualitas intelektual manusia yang disimbolkan dengan menggunakan data Indeks Pembangunan Manusia (IPM) yang diperoleh dari data publikasi BPS.

Metode analisis yang digunakan dalam penelitian ini terdiri dari statistic deskriptif untuk menganalisis data dengan cara menggambarkan data yang telah dikumpulkan tanpa bermaksud membuat kesimpulan atau generalisasi dari data tersebut Sugiyono (2009) dan denan menggunakan statistik inferensial untuk menguji hipotesis terhadap data yang ada dan menarik kesimpulan dengan melakukan regresi data panel.

\section{HASIL PENELITIAN}

4.1. Analisis Deskriptif
Berikut adalah gambaran umum bagaimana perkembangan dan kondisi perekonomian, fiskal maupun pengembangan manusia di Provinsi Kalimantan Timur.

\section{Pertumbuhan Ekonomi}

Pada gambar 3 dapat dilihat bahwa pertumbuhan ekonomi di hampir setiap kabupaten/kota cenderung mengalami penurunan setiap tahunnya. Hampir seluruh daerah pernah mengalami pertumbuhan ekonomi negatif kecuali Kota Balikpapan dan Samarinda yang berhasil menjaga tren positif walaupun juga mengalami penurunan pertumbuhan ekonomi. Kabupaten Berau mengalami pertumbuhan ekonomi paling tinggi yaitu pada tahun 2011 sebesar $21,75 \%$ dan juga memiliki rata-rata pertumbuhan paling besar di antara daerah lainnya yaitu sebesar 10,03\%. Sebaliknya, daerah yang mengalami pertumbuhan ekonomi paling rendah yaitu Kota Bontang dengan pertumbuhan sebesar $-9,18 \%$ dan juga memiliki rata-rata terkecil dibandingkan daerah lain yaitu sebesar $-3,78 \%$. Secara umum tren pertumbuhan ekonomi Provinsi Kalimantan Timur memang cenderung mengalami penurunan bahkan menyentuh angka minus di tahun tahun 2015 dan 2016.

Gambar 3: Laju Pertumbuhan Ekonomi Kabupaten/Kota Provinsi Kalimantan Timur

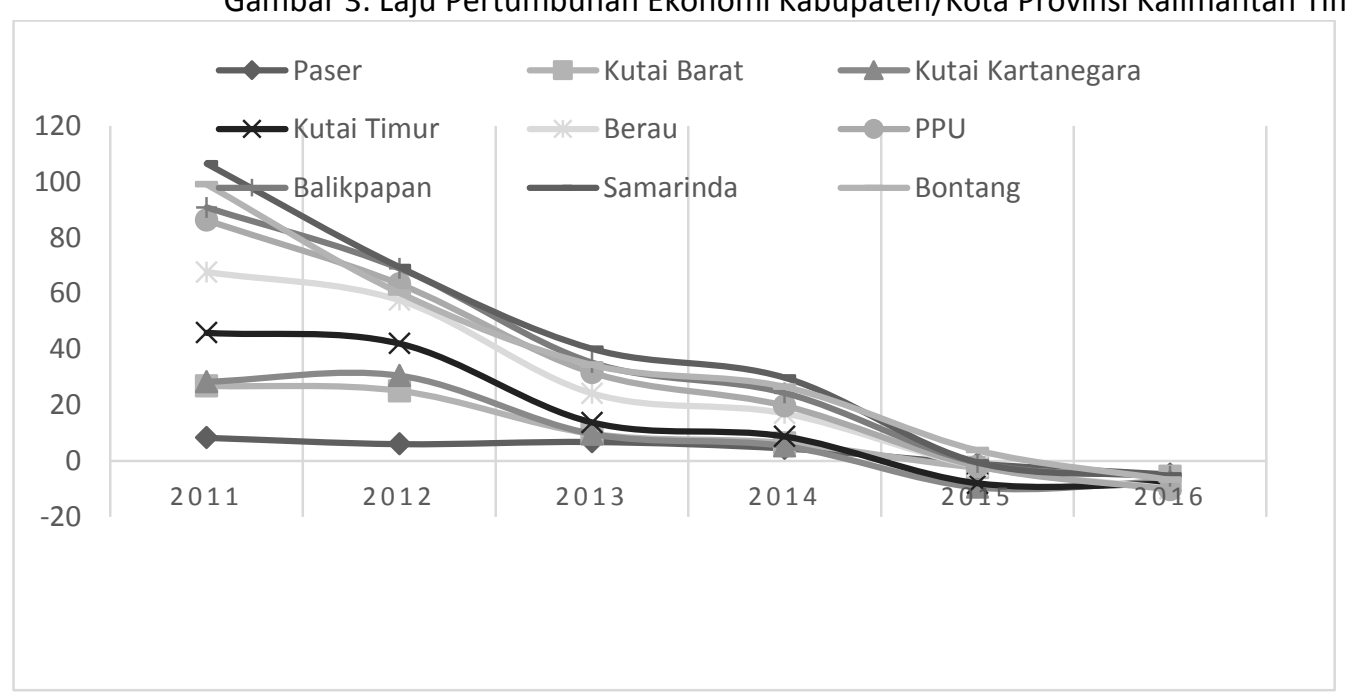

Sumber: Diolah dari Badan Pusat Statistik

\section{Desentralisasi Fiskal}

Pada Tabel 1, secara umum pemerintah Provinsi Kalimantan Timur memiliki derajat desentralisasi fiskal di atas $90 \%$. Hal ini menandakan bahwa seluruh pengeluaran belanja Provinsi Kalimantan Timur dapat dibiayai dari pendapatan PAD dan DBH yang merupakan pendapatan yang bersumber dari pemanfaatan sumber daya alam, pajak maupun retribusi yang diterima dari masyakarat. Semakin tinggi derajat desentralisasi fiskal suatu daerah, menandakan bahwa semakin mandiri suatu wilayah dalam membiayai dan mengurus rumah tangganya sendiri.

Kabupaten/Kota di Provinsi Kalimantan Timur memiliki derajat desentralisasi fiskal yang berbeda, tergantung dari besarnya pendapatan PAD dan DBH serta pengeluaran belanja masing-masing daerah. Secara keseluruhan, rata-rata nilai derajat desentralisasi fiskal sudah di atas $66 \%$. Daerah yang memiliki derajat desentraliisasi fiskal yang paling 
besar adalah Kabupaten Kutai Kartanegara dengan angka sebesar $125,31 \%$ pada tahun 2011. Hal ini mengisyaratkan bahwa Kabupaten Kutai Kartanegara sudah memiliki kemandirian fiskal karena mampu memperoleh pendapatan lebih besar dibandingkan dengan biaya untuk kebutuhan belanja daerahnya. Namun, lain halnya dengan Kota Samarinda yang mana pada tahun 2015 memiliki derajat desentralisasi fiskal hanya sebesar 39,35\%. Sisanya masih bersumber dari Lain-lain Pendapatan Daerah yang Sah sebesar 31\% dari total pendapatan dan Dana Alokasi Umum dari pemerintah pusat. Ini menunjukkan bahwa Kota Samarinda masih belum cukup kuat sumber pendapatan daerahnya dan perlu untuk melakukan penggalian potensi pendapatan daerahnya.

Investasi

Salah satu alat untuk menunjang roda perekonomian dalam suatu daerah yaitu kemampuan daerah dalam membangun infrastruktur daerah. Semakin besar belanja proporsi belanja modal pemerintah yang digunakan untuk membangun sarana dan prasarana perekonomian daerah, maka semakin besar pula potensi untuk menciptakan peningkatan perekonomian. Berikut adalah tabel rasio investasi pemerintah Kabupaten/Kota di Provinsi Kalimantan Timur.

Tabel 1: Derajat Desentralisasi Fiskal Kab/Kota Prov. Kalimantan Timur

\begin{tabular}{|c|c|c|c|c|c|c|c|}
\hline \multirow{2}{*}{ No } & \multirow{2}{*}{ Kabupaten/Kota } & \multicolumn{6}{|c|}{ Derajat Desentralisasi Fiskal (dalam persen) } \\
\hline & & 2011 & 2012 & 2013 & 2014 & 2015 & 2016 \\
\hline 1 & Berau & 76.65 & 73.29 & 63.53 & 61.19 & 48.70 & 45.89 \\
\hline 2 & Kutai Barat & 76.65 & 73.29 & 63.53 & 61.19 & 48.70 & 45.89 \\
\hline 3 & Kutai Kartanegara & $\begin{array}{l}125.3 \\
1\end{array}$ & 108.68 & 67.90 & 83.98 & 63.12 & 85.23 \\
\hline 4 & Kutai Timur & 74.75 & 68.02 & 67.94 & 68.05 & 60.53 & 65.44 \\
\hline 5 & Paser & 77.43 & 62.29 & 48.24 & 57.04 & 49.22 & 66.16 \\
\hline 6 & $\begin{array}{l}\text { Penajam Paser } \\
\text { Utara }\end{array}$ & 79.74 & 79.14 & 66.12 & 64.44 & 60.10 & 69.44 \\
\hline 7 & Balikpapan & 72.84 & 77.31 & 53.78 & 64.66 & 45.62 & 54.88 \\
\hline 8 & Bontang & 99.12 & 87.04 & 66.50 & 74.62 & 56.45 & 63.00 \\
\hline 9 & Samarinda & 73.99 & 66.45 & 42.34 & 42.26 & 39.35 & 46.63 \\
\hline 10 & Kalimantan Timur & 98.88 & 95.71 & 95.92 & 96.21 & 92.51 & 86.08 \\
\hline
\end{tabular}

Sumber: Diolah dari Badan Pusat Statistik

Berdasarkan Tabel 2 di bawah, dapat dilihat bahwa setelah tahun 2013, hampir seluruh daerah cenderung mengalami penurunan rasio investasinya. Secara keseluruhan, rata-rata investasi kabupaten/kota hanya sebesar 37,62\%. Kabupaten/Kota yang memiliki rata-rata paling tinggi yaitu Kabupaten Berau yakni sebesar $42,51 \%$. Hampir setiap tahunnya Kabupaten Berau memiliki proporsi belanja modal terhadap total belanja di atas $40 \%$ kecuali pada tahun 2016 yang merosot ke angka $34,29 \%$ saja. Rasio investasi terbesar terjadi pada tahun 2012 di Kabupaten Penajam Paser Utara yaitu sebesar 52,65\%. Hal ini berarti bahwa lebih dari setengah kebutuhan belanja Kabupaten Paser Utara dialokasikan untuk belanja modal pemerintah daerah. Namun berbeda halnya dengan Kabupaten Kutai Kartanegara yang hanya memiliki rasio investasi hanya sebesar $15,15 \%$ pada tahun 2016. Padahal pada tahun sebelumnya, Kabupaten Kutai Kartanegara memiliki rasio investasi yang cukup besar yakni $41,63 \%$.

Tabel 2: Rasio Investasi Pemerintah Kab/Kota Provinsi Kalimantan Timur

\begin{tabular}{|c|c|c|c|c|c|c|c|}
\hline \multirow{2}{*}{ No } & \multirow[b]{2}{*}{ Kabupaten/Kota } & \multicolumn{6}{|c|}{ Investasi (dalam persentase) } \\
\hline & & 2011 & 2012 & 2013 & 2014 & 2015 & 2016 \\
\hline 1 & Berau & 43.18 & 44.86 & 40.13 & 46.03 & 46.58 & 34.29 \\
\hline 2 & Kutai Barat & 39.18 & 41.85 & 49.17 & 38.36 & 41.50 & 24.26 \\
\hline 3 & Kutai Kartanegara & 32.05 & 36.77 & 46.27 & 40.08 & 41.63 & 15.15 \\
\hline 4 & Kutai Timur & 35.96 & 44.71 & 47.33 & 44.49 & 38.77 & 36.03 \\
\hline
\end{tabular}




\begin{tabular}{|c|c|c|c|c|c|c|c|}
\hline 5 & Paser & 38.73 & 50.37 & 48.90 & 41.57 & 35.89 & 21.46 \\
\hline 6 & $\begin{array}{l}\text { Penajam Paser } \\
\text { Utara }\end{array}$ & 47.76 & 52.65 & 46.61 & 38.93 & 32.34 & 33.62 \\
\hline 7 & Balikpapan & 20.94 & 28.61 & 44.78 & 41.32 & 37.50 & 26.67 \\
\hline 8 & Bontang & 27.30 & 32.50 & 37.21 & 32.56 & 35.54 & 21.45 \\
\hline 9 & Samarinda & 19.05 & 35.30 & 44.62 & 41.31 & 37.35 & 29.84 \\
\hline 10 & Kalimantan Timur & 21.81 & 22.04 & 26.50 & 19.61 & 19.67 & 20.68 \\
\hline
\end{tabular}

Sumber: Diolah dari Badan Pusat Statistik

\section{Indeks Pembangunan Manusia}

Pada Tabel 3, terlihat bahwa IPM seluruh daerah selalu meningkat setiap tahunnya. Rata-rata peningkatan IPM secara keseluruhan yaitu sebesar 0,57 poin dengan rata-rata IPM 72,45. Capaian ratarata IPM sebesar 72,45 sudah termasuk dalam kategori IPM tinggi. Peningkatan IPM paling besar yaitu sebesar 1,59 Poin yang terjadi pada tahun 2013 di Kabupaten Kutai Kartanegara. Sedangkan angka IPM tertinggi dimiliki oleh Kota Bontang dengan angka 78,92 pada tahun 2016. Hal tersebut menandakan bahwa Kota Bontang sudah memiliki kualitas kesehatan, pendidikan maupun pendapatan per kapita yang lebih baik di bandingkan daerah lainnya. Meskipun memiliki IPM tertinggi, pada tahun yang sama Kota Bondang mencatat peningkatan paling kecil yakni hanya sebesar 0,14 poin dari tahun sebelumnya. Sedangkan IPM terendah dicatat oleh Kabupaten Penajam Paser Utara yang memperoleh angka IPM sebesar 66,92 pada tahun 2011. Hingga tahun 2016, IPM Kabupaten Penajam Paser Utara dan Kutai Barat masih berada di angka masing-masing 69,96 dan 69,99 yang berarti masih dalam kategori IPM sedang.

Tabel 3: Indeks Pembangunan Manusia Kab/Kota Provinsi Kalimantan Timur

\begin{tabular}{|c|c|c|c|c|c|c|c|}
\hline \multirow{2}{*}{ No } & \multirow{2}{*}{ Kabupaten/Kota } & \multicolumn{6}{|c|}{ Indeks Pembangunan Manusia } \\
\hline & & 2011 & 2012 & 2013 & 2014 & 2015 & 2016 \\
\hline 1 & Berau & 70.43 & 70.77 & 72.02 & 72.26 & 72.72 & 73.05 \\
\hline 2 & Kutai Barat & 66.92 & 67.14 & 68.13 & 68.91 & 69.34 & 69.99 \\
\hline 3 & Kutai Kartanegara & 68.47 & 69.12 & 70.71 & 71.20 & 71.78 & 72.19 \\
\hline 4 & Kutai Timur & 67.73 & 68.71 & 69.79 & 70.39 & 70.76 & 71.10 \\
\hline 5 & Paser & 67.11 & 68.18 & 69.61 & 69.87 & 70.30 & 71.00 \\
\hline 6 & Penajam Paser Utara & 66.92 & 67.17 & 68.07 & 68.60 & 69.26 & 69.96 \\
\hline 7 & Balikpapan & 76.02 & 76.56 & 77.53 & 77.93 & 78.18 & 78.57 \\
\hline 8 & Bontang & 77.25 & 77.55 & 78.34 & 78.58 & 78.78 & 78.92 \\
\hline 9 & Samarinda & 77.05 & 77.34 & 77.84 & 78.39 & 78.69 & 78.91 \\
\hline 10 & Kalimantan Timur & 72.02 & 72.62 & 73.21 & 73.82 & 74.17 & 74.59 \\
\hline
\end{tabular}

\subsection{Analisis Regresi}

Sumber: Diolah dari Badan Pusat Statistik
Untuk melakukan analisis regresi, perlu dilakukan pemilihan model estimasi terbaik antara Pooled Least Square (PLS), Fixed Effect Models (FEM) dan Random Effect Models (REM). Untuk memilih model yang terbaik dari ketiga model metode di atas, dilakukan Uji Chow, Uji Hausman dan Uji Lagrange Multiplier. Uji Chow digunakan untuk memilih mana yang terbaik di antara metode PLS dan FEM. Uji Hausman untuk memilih model FEM atau REM serta Uji Lagrange Multiplier untuk memilih model antara REM dan PLS.

Berdasarkan Uji Chow disimpulkan bahwa model terbaik yang dipilih adalah Fixed Effect
Models (FEM). Kemudian berdasarkan Uji Hausman dipilih Model FEM sebagai model yang terbaik.

\section{Uji Asumsi Klasik}

Setelah memilih model estimasi, langkah selanjutnya adalah melakukan uji asumsi klasik. Uji asumsi klasik yang dilakukan yaitu uji multikolinearitas, uji normalitas, uni autokorelasi dan uji heteroskedastisitas.

a. Uji Multikolinearitas

Berikut adalah hasil uji multikolinearitas dengan melihat korelasi antar variabel dalam model regresi:

Tabel 4: Hasil Uji Multikolinearitas 


\begin{tabular}{||crrc||}
\hline & DFD & INVESTASI & IPM \\
\hline \hline DFD & 1.000000 & -0.198185 & -0.214106 \\
INVESTASI & -0.198185 & 1.000000 & -0.415674 \\
IPM & -0.214106 & -0.415674 & 1.000000 \\
\hline
\end{tabular}

Sumber: Diolah dengan Eviews 8

Berdasarkan Tabel 4 dapat dilihat bahwa seluruh variable independen memiliki nilai koefisien korelasi di bawah 0,08. Hal tersebut dapat disimpulkan bahwa dalam model regresi yang digunakan tidak terdapat masalah multikolinearitas.

b. Uji Heterokedastisitas

Tabel 5: Hasil Uji Glejser

\begin{tabular}{||crrrr||}
\hline \hline Variable & Coefficient & Std. Error & t-Statistic & Prob. \\
\hline \hline C & 73.35489 & 41.69913 & 1.759147 & 0.0858 \\
DFD & -1.086766 & 4.429156 & -0.245366 & 0.8074 \\
INVESTASI & -8.334719 & 5.067514 & -1.644735 & 0.1075 \\
IPM & -0.916022 & 0.525696 & -1.742493 & 0.0887 \\
\hline \hline \multicolumn{5}{|c||}{ Effects Specification } \\
\hline \hline \multicolumn{5}{|c|}{ Cross-section fixed (dummy variables) } \\
\hline \hline
\end{tabular}

\section{Sumber: Diolah dengan Eviews 8}

c. Uji Autokorelasi

Berikut adalah hasil Uji Autokorelasi dengan menggunakan Durbin Watson dengan tingkat signifikansi $(\alpha) 5 \%$.

Tabel 6: Uji Durbin Watson

\begin{tabular}{c|c|c|c}
\hline DW & DL & DU & 4-DW \\
\hline 1.877 .872 & 144.636 & 167.998 & 2.122 .128 \\
\hline
\end{tabular}

Sumber: Diolah dengan Eviews 8

Hasil uji Durbin Watsin pada Tabel 6 dapat dilihat bahwa nilai DW sebesar 1.877872 lebih besar daripada DU dengan nilai 1.67998. Selain itu, nilai dari (4 - DW) sebesar 2.122128 juga lebih besar dibandingkan dengan nilai DU 1.67998. Berdasarkan hasil tersebut dapat disimpulkan bahwa model regresi telah memenuhi syarat uji Durbin Watson dengan hasil bahwa tidak ditemukannya masalah autokorelasi dalam model regresi yang digunakan.

d. Uji Normalitas

Pada tabel 7 dapat dilihat bahwa nilai Jarque-Bera sebesar 0,794558 lebih kecil dibandingkan dengan Chi square table yaitu sebesar 70,99 maka $\mathrm{HO}$ diterima dan H1 ditolak. Selanjutnya jika dilihat nilai Probabilitas yaitu sebesar 0,672146, nilainya lebih besar dibandingkan dengan tingkat signifikansi 0,05 maka Ho diterima dan $\mathrm{H} 1$ ditolak.

Tabel 7: Hasil Uji Jarque-Bera

\begin{tabular}{|l|l|lr|l}
\hline Variabel & $\begin{array}{l}\text { Nilai Jarque- } \\
\text { Bera }\end{array}$ & $\begin{array}{lr}\text { Chi square } \\
\text { table } & \text { pada } \\
\alpha=5 \%\end{array}$ & Prob. \\
\hline PE & 0.794558 & 70.99 & 0.672146 \\
\hline
\end{tabular}

Sumber: Diolah dengan Eviews 8

e. Analisis Regresi Berganda

Berikut adalah hasil dari regresi dengan menggunakan metode Fixed Effect Models.

Tabel 8: Hasil Regresi Berganda dengan FEM
Pada Tabel 5 dapat dilihat bahwa nilai probabilitas dari masing-masing variabel bebas memiliki nilai di atas 0,05. Hal tersebut menandakan bahwa model regresi bersifat homoskedastisitas yang berarti bahwa nilai varians dari gangguan (error) pada setiap level variabel independen adalah sama/konstan. Sehingga dapat disimpulkan bahwa model regresi terbebas dari masalah heteroskedastisitas.

Berikut adalah hasil Uji Glejser untuk mendeteksi masalah heteroskedastisitas:

\begin{tabular}{|c|c|c|c|c|}
\hline Variable & Coefficient & Std. Error & t-Statistic & Prab. \\
\hline C & 389.6700 & 84.83751 & 4.593133 & 0.0000 \\
\hline DFD & -13.03676 & 9.011186 & -1.446731 & 0.1554 \\
\hline INVESTASI & -8.888875 & 10.30993 & -0.862166 & 0.3935 \\
\hline IPM & -5.159163 & 1.069537 & -4.823736 & 0.0000 \\
\hline \multicolumn{5}{|c|}{ Effects Specification } \\
\hline \multicolumn{5}{|c|}{ Cross-section fixed (dummy variables) } \\
\hline R-squared & 0.672067 & \multirow{6}{*}{\multicolumn{2}{|c|}{$\begin{array}{l}\text { Mean dependent var } \\
\text { S.D. dependent var } \\
\text { Akaike info criterion } \\
\text { Schwarz criterion } \\
\text { Hannan-Quinn criter. } \\
\text { Durbin-Watson stat }\end{array}$}} & 4.026 \\
\hline Adjusted R-squared & 0.586180 & & & 6.981180 \\
\hline S.E. of regression & 4.490914 & & & 6.035120 \\
\hline Sum squared resid & 847.0689 & & & 6.477116 \\
\hline Log likelihood & -150.9482 & & & 6.205580 \\
\hline F-statistic & 7.824992 & & & 1.877872 \\
\hline Prob(F-statistic) & 0.000000 & & & \\
\hline
\end{tabular}

Sumber: Diolah dengan Eviews 8

Estimasi model regresi yang terbentuk:

$P E_{i, t}=389,67-13,03676 D F_{i, t}-8,888875 I P_{i, t}$

f. Koefisien Determinasi

$$
\text { - 5,159163IPM } M_{i, t}+\varepsilon_{i t}
$$

Nilai koefisien determinasi (R2) yang diperoleh terhadap variabel pertumbuhan ekonomi adalah sebesar 0,672067. Hal tersebut berarti bahwa variabel pertumbuhan ekonomi dalam model sebesar $67,2067 \%$ dipengaruhi oleh variabel-variabel bebas yang ada dalam model yaitu desentralisasi fiskal, investasi dan indeks pembangunan manusia. Sementara $32,7933 \%$ sisanya dijelaskan oleh variabel di luar model dan faktor-faktor lainnya.

g. Uji Signifikasni Simultan (Uji F)

Pada Tabel 8, dapat ditentukan signifikansi simultan pada model regresi dengan melihat nilai dari Probabilitas F-Statistik sebesar 0,000000 yang lebih kecil dari nilai signifikansi ( $\alpha$ ) 5\%. Dapat disimpulkan bahwa dalam model tersebut seluruh variabel independen secara bersamaan berpengaruh signifikan terhadap variabel dependennya.

h. Ujii Signifikansi Individu (Uji t)

Tabel 9: Hasil Konversi Nilai Probabilitas dengan Asumsi One-Tailed

\begin{tabular}{|l|l|l|}
\hline Variabel & $\begin{array}{l}\text { Two-Tailed } \\
\text { Prob. }\end{array}$ & $\begin{array}{l}\text { One-Tailed } \\
\text { Prob }\end{array}$ \\
\hline DF & 0,1554 & 0,0777 \\
\hline INV & 0,3935 & 0,19675 \\
\hline IPM & 0,0000 & 0,0000 \\
\hline
\end{tabular}

Sumber: Diolah dengan Eviews 8

Berdasarkan Tabel 9, dapat diinterpretasikan bahwa variabel independen yakni DF dan INV secara individu tidak berpengaruh signifikan terhadap PE sebagai variabel dependen pada tingkat keyakinan 
95\%. Hal tersebut dapat dilihat pada nilai Prob $t$ statistic DF dan INV masing-masing sebesar 0,0777 dan 0,19675 , yang nilainya lebih besar dari nilai signifikansi (a) 5\%. Berbeda halnya dengan nilai Prob t-statistic variabel IPM sebesar 0,0000 yang nilai lebih kecil sari nilai signifikansi a 5\%. Sehingga dapat disimpulkan bahwa variabel IPM berpengaruh signifikan terhadap variabel PE sebagai variabel dependen.

\section{Hasil Pengujian Hipotesis}

Berdasarkan uji $t$ yang telah dilakukan sebelumnya, langkah selanjutnya adalah melakukan pengujian hipotesis dengan menggunakan asumsi OneTailed. Hasil pengujian hipotesis penelitian dapat dijelaskan sebagai berikut:

\section{Pengaruh Desentralisasi Fiskal terhadap}

\section{Pertumbuhan Ekonomi}

Hipotesis yang digunakan adalah sebagai berikut:

$\mathrm{H}_{1}$ : Desentralisasi fiskal berpengaruh positif secara signifikan terhadap pertumbuhan ekonomi.

Berdasarkan Tabel 9, dapat dilihat variabel desentralisasi fiskal memiliki nilai probabilitas tstatistik yaitu sebesar 0,0777 . Nilai tersebut lebih dari 0,05 yang berarti bahwa tidak terdapat pengaruh signifikan desentralisasi fiskal terhadap pertumbuhan ekonomi. Nilai koefisien menunjukkan angka -13,03676 yang dapat disimpulkan bahwa desentralisasi fiskal berpengaruh negatif secara tidak signifikan terhadap pertumbuhan ekonomi. Sehingga $\mathrm{H}_{1}$ penelitian ditolak. Pengaruh Investasi terhadap Pertumbuhan Ekonomi Hipotesis yang digunakan selanjutnya adalah sebagai berikut:

$\mathrm{H}_{2}$ : Investasi berpengaruh positif secara signifikan terhadap pertumbuhan ekonomi.

Berdasarkan Tabel 9, dapat dilihat variabel investasi memiliki nilai probabilitas t-statistik yaitu sebesar 0,19675. Nilai tersebut lebih dari tingkat signifikansi $(\alpha)$ 0,05 yang berarti bahwa tidak terdapat pengaruh signifikan investasi terhadap pertumbuhan ekonomi. Nilai koefisien menunjukkan angka -8,888875 yang dapat disimpulkan bahwa investasi berpengaruh negatif secara tidak signifikan terhadap pertumbuhan ekonomi. Sehingga $\mathrm{H}_{2}$ penelitian ditolak.

Pengaruh Indeks Pembangunan Manusia terhadap Pertumbuhan Ekonomi

Hipotesis ketiga yang digunakan adalah sebagai berikut: $\mathrm{H}_{3}$ : Indeks Pembangunan Manusia berpengaruh positif secara signifikan terhadap pertumbuhan ekonomi.

Tabel 9, dapat dilihat variabel indeks pembangunan manusia memiliki nilai probabilitas tstatistic yaitu sebesar 0,0000 . Nilai tersebut kurang dari tingkat signifikansi $(\alpha)$ 0,05 yang berarti bahwa terdapat pengaruh signifikan indeks pembangunan manusia terhadap pertumbuhan ekonomi. Nilai koefisien menunjukkan angka $-5,159163$ sehingga dapat disimpulkan bahwa indeks pembangunan manusia berpengaruh negatif secara signifikan terhadap pertumbuhan ekonomi. Dengan demikian maka $\mathrm{H}_{3}$ penelitian ditolak.

Pembahasan

Pengaruh Desentralisasi Fiskal terhadap Pertumbuhan Ekonomi.

Berdasarkan hasil regresi linear berganda pada Tabel 8, variabel desentralisasi fiskal memiliki koefisien negatif $(-13,03676)$ dengan nilai probabilitas $t$-statistic di atas 0,05. Hal tersebut berarti bahwa desentralisasi fiskal berpengaruh negatif secara tidak signifikan terhadap pertumbuhan ekonomi. Sehingga dapat dikatakan semakin tinggi desentralisasi fiskal maka semakin rendah pertumbuhan ekonomi. Hasil tersebut sejalan dengan penelitian Jumadi et al. (2013) bahwa desentralisasi fiskal memiliki pengaruh negatif dan tidak signifikan terhadap pertumbuhan ekonomi. Begitu juga penelitian yang dilakukan oleh Saputra \& Mahmudi (2012), Kharisma (2013) dan Situngkir et al. (2014) yang mengatakan bahwa desentralisasi fiskal berpengaruh negatif terhadap pertumbuhan ekonomi.

Atas hasil penelitian tersebut, penulis menduga adanya ketidakefisienan dan ketidakefektifan pemerintah daerah dalam mengelola desentralisasi fiskal di daerahnya. Dalam artian besarnya derajat desentralisasi fiskal daerah belum mampu dimanfaatkan untuk penyediaan layanan publik yang dapat mendorong dan meningkatkan perekonomian ataupun kesejahteraan masyarakat. Sehingga pengeluaran pemerintah yang dikeluarkan tidak dapat merangsang pertumbuhan ekonomi regional di wilayah Provinsi Kalimantan Timur. Berikut adalah tabel ratarata proporsi belanja di setiap daerah di Provinsi Kalimantan Timur.

Dalam Laporan Keuangan Pemerintah Pusat, melemahnya perekonomian global ditandai dengan rendahnya harga komoditas dan menurunnya perdagangan dunia. Penurunan harga komoditas dunia termasuk minyak bumi dan batu bara turut mengambil andil dalam memicu perlambatan ekonomi dunia yang hanya mencapai 3,1 persen, turun dibandingkan dengan tahun 2014 yang mencapai 3,4 persen. Dampak lesuhnya perekonomian dunia terutama pada sektor komoditas alam seperti minyak bumi dan batu bara membawa dampak tersendiri bagi Provinsi Kalimantan Timur khususnya. Tabel 10 adalah nilai ekspor Provinsi Kalimantan Timur selama tahun 2011-2016. Tabel 10: Nilai Ekspor Provinsi Kalimantan Timur Tahun 2011-2016

\begin{tabular}{|l|c|c|c|c|c|c|}
\hline \multirow{2}{*}{ Jenis Ekspor } & \multicolumn{7}{|c|}{ Nilai Ekspor Tahunan (Dalam Juta US\$) } \\
\cline { 2 - 7 } & $\mathbf{2 0 1 1}$ & $\mathbf{2 0 1 2}$ & $\mathbf{2 0 1 3}$ & $\mathbf{2 0 1 4}$ & $\mathbf{2 0 1 5}$ & $\mathbf{2 0 1 6}$ \\
\hline Ekspor Migas & $18.655,7$ & $14.994,5$ & $12.843,5$ & $10.867,28$ & $6.414,17$ & $3.781,67$ \\
\hline
\end{tabular}




\begin{tabular}{|l|r|r|r|r|r|r|} 
Ekspor Non Migas & $18.417,8$ & $17.796,69$ & $18.159,59$ & $13.805,9$ & $11.069,11$ & $10.072,71$ \\
\hline Ekspor Total & $37.073,5$ & $32.791,18$ & $31.003,08$ & $24.673,18$ & $17.483,27$ & $13.854,37$ \\
\hline
\end{tabular}

\section{Sumber: Diolah dari Badan Pusat Statistik}

Berdasarkan data pada Tabel 11, membuktikan bahwa terjadinya penurunan ekonomi global membawa dampak bagi Provinsi Kalimantan Timur sebagai salah satu Provinsi penghasil sumber daya alam terbesar di Indonesia. Nilai ekspor migas maupun non migas mengalami penurunan setiap tahunnya. Penurunan paling signifikan terjadi pada ekspor migas yang pada tahun 2011 berada di angka 18.655,7 merosot tajam ke angka 3.781,67. Begitu pula ekspor non migas yang turun dari angka $18.417,8$ ke angka $10.072,71$. Penurunan dari sektor ekspor Provinsi Kalimantan Timur ini menjadi penyebab menurun pula nya pendapatan daerah dari sektor pertambangan dan penggalian. Namun, penurunan pendapatan tersebut tidak sepenuhnya dapat disimpulkan bahwa desentralisasi fiskal berpengaruh negatif terhadap pertumbuhan ekonomi karena hubungan kedua variabel tersebut tidaklah signifikan.

1. Pengaruh Investasi Terhadap Pertumbuhan Ekonomi

Berdasarkan hasil regresi linear berganda pada Tabel 11, variabel investasi memiliki nilai probabilitas t-

statistik di atas 0,05 dengan koefisien negatif ($8,888875)$. Hal tersebut menandakan bahwa variabel investasi berpengaruh negatif secara tidak signifikan terhadap pertumbuhan ekonomi. Sehingga dapat dikatakan bahwa semakin tinggi nilai investasi pemerintah maka semakin rendah pertumbuhan ekonomi. Hasil ini bertentangan dengan penelitian yang dilakukan oleh Situngkir et al. (2014) yang menemukan bahwa investasi berpengaruh positif secara signifikan terhadap pertumbuhan ekonomi. Penelitian tersebut didukung juga oleh penelitian Satria (2016) dan Dwirandra (2013) yang memperoleh hasil yang sama bahwa investasi atau keserasian belanja modal daerah berpengaruh positif terhadap pertumbuhan ekonomi. Begitu pula dengan penelitian Jumadi et al. (2013) yang menemukan bahwa faktor input yaitu belanja modal pemerintah daerah memiliki pengaruh positif terhadap pertumbuhan ekonomi regional. Mereka mengatakan bahwa dengan infrastruktur yang berkualitas, aktivitas mobilisasi, dan aktivitas perekonomian dapat berjalan dengan baik dan lancar.

Tabel 10: Rata-rata Proporsi Belanja di Kab/Kota Provinsi Kalimantan Timur

\begin{tabular}{|l|r|r|r|r|r|}
\hline \multicolumn{1}{|c|}{ Kabupaten/Kota } & \multicolumn{1}{c|}{$\begin{array}{c}\text { Belanja } \\
\text { Pegawai }\end{array}$} & \multicolumn{1}{c|}{$\begin{array}{c}\text { Belanja Barang } \\
\text { dan Jasa }\end{array}$} & \multicolumn{1}{c|}{$\begin{array}{c}\text { Belanja } \\
\text { Modal }\end{array}$} & \multicolumn{1}{c|}{$\begin{array}{c}\text { Belanja } \\
\text { Sosial }\end{array}$} & \multicolumn{1}{c|}{$\begin{array}{c}\text { Belanja } \\
\text { Lain }\end{array}$} \\
\hline Kab. Berau & $28.53 \%$ & $21.39 \%$ & $42.51 \%$ & $0.38 \%$ & $7.18 \%$ \\
\hline Kab. Kutai Kartanegara & $30.92 \%$ & $20.32 \%$ & $35.33 \%$ & $1.05 \%$ & $12.38 \%$ \\
\hline Kab. Kutai Barat & $30.25 \%$ & $19.13 \%$ & $39.05 \%$ & $2.37 \%$ & $9.20 \%$ \\
\hline Kab. Kutai Timur & $24.57 \%$ & $24.40 \%$ & $41.22 \%$ & $1.04 \%$ & $8.77 \%$ \\
\hline Kab. Paser & $33.65 \%$ & $14.34 \%$ & $39.49 \%$ & $1.02 \%$ & $11.51 \%$ \\
\hline Kota Balikpapan & $30.42 \%$ & $24.62 \%$ & $33.30 \%$ & $1.56 \%$ & $10.09 \%$ \\
\hline Kota Bontang & $30.97 \%$ & $30.76 \%$ & $31.09 \%$ & $0.42 \%$ & $6.75 \%$ \\
\hline Kota Samarinda & $39.76 \%$ & $17.39 \%$ & $34.58 \%$ & $0.21 \%$ & $8.06 \%$ \\
\hline Kab. Penajam Paser Utara & $32.36 \%$ & $18.62 \%$ & $41.99 \%$ & $0.28 \%$ & $6.76 \%$ \\
\hline
\end{tabular}

Sumber: Diolah dari Direktorat Jenderal Perimbangan Keuangan

Namun, hasil penelitian penulis sejalan dengan penelitian yang dilakukan oleh Sulistiawati (2012) yang memperoleh temuan bahwa investasi pemerintah berdampak negatif dan tidak signifikan terhadap pertumbuhan ekonomi. Begitu pula penelitian Bado (2015) dan Bati (2009) yang menemukan bahwa investasi atau belanja modal tidak berpengaruh secara signifikan terhadap pertumbuhan ekonomi.

Pada bahasan sebelumnya, W. E. Oates (1993) berpendapat bahwa pengeluaran yang dialokasikan pada sektor infrastruktur dan sektor sosial akan efektif dalam mendorong perekonomian. Infrastruktur yang baik akan menunjang aktivitas perekonomian daerah seperti mempermudah jalur distribusi barang dan jasa sehingga dapat memacu tingkat produksi industri dan menarik para investor untuk berinvestasi di daerah. Dampak multiplier adalah akan terciptanya lapangan pekerjaan baru dan meningkatkan kesejahteraan masyarakat dan pada akhirnya akan berpengaruh pada peningkatan pertumbuhan ekonomi regional suatu daerah. Namun, menurut Martinez \& McNab (2001) hal tersebut tidak akan terjadi apabila desentralisasi fiskal (dalam konteks belanja modal) dapat berjalan efektif.

Peran pemerintah sangat penting dalam menentukan kebijakan terkait dengan pembangunan infrastruktur yang secara produktif dapat menstimulus roda perekonomian daerah. Berdasarkan Tabel 4.14, 
dapat dilihat bahwa proporsi belanja modal terhadap total belanja di seluruh daerah di Kalimantan Timur selama periode 2011 sampai 2016 memiliki nilai yang besar yakni di atas $31 \%$. Bahkan alokasi belanja modal tersebut lebih besar dibandingkan dengan alokasi belanja pegawai, belanja barang dan jasa, belanja sosial, dan belanja lainnya. Hal ini dapat menandakan bahwa pemerintah Kabupaten/Kota di Provinsi Kalimantan Timur sedang melakukan percepatan pembangunan untuk terus memperbaiki dan menggali potensi daerahnya.

2. Pengaruh Indeks Pembangunan Manusia Terhadap Pertumbuhan Ekonomi

Berdasarkan hasil regresi berganda pada Tabel 8 , variabel indeks pembangunan manusia memiliki nilai koefisien negatif $(-5,159163)$ dengan nilai probabilitas t-statistic dibawah 0,05 yaitu sebesar 0,0000. Dapat disimpulkan bahwa variabel indeks pembangunan manusia berpengaruh negatif secara signifikan terhadap variabel terikat pertumbuhan ekonomi. Sehingga dapat dikatakan bahwa apabila terjadi peningkatan indeks pembangunan manusia sebesar $1 \%$, maka akan menurunkan pertumbuhan ekonomi sebesar 5,159163\% dengan asumsi variabel lain bernilai tetap (ceteris paribus). Hasil ini sejalan dengan penelitian yang dilakukan oleh Muqorrobin \& Soejoto (2017) yang memperoleh temuan bahwa indeks pembangunan manusia berpengaruh negatif dan signifikan terhadap pertumbuhan ekonomi. Hasil ini tidak sejalan dengan penelitian dilakukan oleh Jumadi et al. (2013) yang memperoleh temuan bahwa indeks pembangunan manusia memiliki pengaruh positif dan signifikan terhadap pertumbuhan ekonomi. Sama halnya penelitian Situngkir et al. (2014) dan Nurmainah (2013) yang juga menghasilkan temuan bahwa indeks pembangunan manusia secara signifikan berpengaruh positif terhadap pertumbuhan ekonomi.

Berdasarkan hasil tersebut, penulis menduga bahwa indeks pembangunan manusia pada seluruh daerah di Provinsi Kalimantan Timur belum mampu untuk meningkatkan pertumbuhan ekonomi. Indeks pembangunan manusia yang setiap tahunnya cenderung mengalami kenaikan justru tidak diikuti dengan kenaikan pertumbuhan ekonomi. Perubahan masing-masing variabel yang tidak searah ini diduga menjadi penyebab hubungan negatif antara indeks pembangunan manusia terhadap pertumbuhan ekonomi. Namun, indeks pembangunan manusia memiliki keterkaitan atau hubungan yang signifikan terhadap pertumbuhan ekonomi yang berarti bahwa indeks pembangunan manusia dapat berperan dalam memberikan kontribusi terhadap peningkatan pertumbuhan ekonomi.

Indeks pembangunan manusia merupakan salah satu alat ukur dalam menentukan capaian dan kualitas pembangunan suatu wilayah. Nilai IPM dihitung berdasarkan formulasi yang dibuat oleh United Development Programme (UNDP) dengan menggunakan pendekatan baru pada tahun 2010 (Badan Pusat Statistik - Direktorat Analisis dan Pengembangan Statistik, 2015). Komponen indeks pembangunan manusia diformulasikan dari tiga aspek yaitu berdasarkan capaian aspek pendidikan, kesehatan dan standar hidup layak.

a. Aspek Pendidikan

Terdapat dua unsur perhitungan dalam aspek pendidikan yaitu Rata-rata Lama Sekolah (RLS) dan Harapan Lama Sekolah (HLS). Berikut ini adalah tabel rata-rata lama sekolah dan harapan lama sekolah di Kabupaten/Kota Provinsi Kalimantan Timur.

Pada Tabel 12, angka rata-rata lama sekolah di Kabupaten/Kota Provinsi Kalimantan Timur selama tahun 2011 - 2016 berada di atas rata-rata nasional 7,71 kecuali Kabupaten Penajam Paser Utara yang ratarata lama sekolah hanya 7,35. Angka ini menunjukkan bahwa rata-rata tingkat pendidikan penduduk usia sekolah (7 tahun atau lebih) di seluruh Kabupaten/Kota Provinsi Kalimantan Timur dapat menyelesaikan pendidikannya hanya sampai jenjang kelas 1 Sekolah Menengah Pertama (SMP). Sedangkan rata-rata lama sekolah yang tertinggi adalah Kota Balikpapan dengan angka 10,37. Angka tersebut menunjukkan bahwa penduduk usia sekolah di Kota Balikpapan dapat menyelesaikan sekolah sampai jenjang kelas 1 Sekolah Menengah Atas (SMA).

Kemudian pada Tabel 12, dapat dilihat pula nilai Harapan Lama Sekolah di seluruh daerah Provinsi Kaltim. Sebagian besar daerah sudah memiliki angka harapan lama sekolah melebihi rata-rata nasional yaitu 12,14 tahun kecuali Kabupaten Kutai Barat, Kutai Timur dan Penajam Paser Utara yang masih di bawah rata-rata nasional. Walaupun berada di bawah nasional, angka harapan lama sekolah Kabupaten Kutai Timur sudah menyentuh angka 12,05. Angka ini menunjukkan bahwa lamanya sekolah yang diharapkan oleh anak pada usia tertentu ( 7 tahun ke atas) di masa yang akan datang adalah 12,05 tahun atau setara dengan pendidikan SMA hingga lulus. Angka harapan lama sekolah tertinggi adalah Kota Samarinda yang mencapai angka 13,91 yang setara dengan mengenyam pendidikan di bangku kuliah semester IV.

Tabel 12: Harapan Lama Sekolah dan Rata-rata Lama Sekolah

\begin{tabular}{|l|r|r|}
\hline $\begin{array}{c}\text { Kabupaten } \\
\text { Kota }\end{array}$ & $\begin{array}{c}\text { Harapan Lama } \\
\text { Sekolah }\end{array}$ & $\begin{array}{c}\text { Rata-rata Lama } \\
\text { Sekolah }\end{array}$ \\
\hline Pasir & 12.29 & 7.94 \\
\hline Kutai Barat & 11.98 & 7.82 \\
\hline Kutai & 12.77 & 8.46 \\
\hline Kutai Timur & 12.05 & 8.51 \\
\hline Berau & 12.71 & 8.50 \\
\hline
\end{tabular}




\begin{tabular}{|l|r|r|} 
Penajam & 11.72 & 7.35 \\
Paser Utara & 13.06 & 10.37 \\
\hline $\begin{array}{l}\text { Kota } \\
\text { Balikpapan }\end{array}$ & 13.91 & 10.18 \\
\hline Kota & 12.47 & 10.33 \\
\hline Samarinda & 12.15 & 7.71 \\
\hline Kota Bontang & & \\
\hline INDONESIA &
\end{tabular}

Sumber: Diolah dari Badan Pusat Statistik

Berdasarkan data kedua komponen IPM tersebut, dapat disimpulkan bahwa secara keseluruhan rata-rata lama sekolah dan harapan lama sekolah di Provinsi Kalimantan Timur sudah berada di atas rata-rata nasional. Hanya saja ada sedikit ketimpangan pendidikan antara Kabupaten Penajam Paser Utara dan Kota Balikpapan yang mempunyai selisih rata-rata lama sekolah hingga 3 tahun. Selain itu, rata-rata seluruh daerah hanya menyentuh angka 8,83 yang berarti bahwa penyelesaian Pendidikan di usia sekolah ratarata seluruh daerah hanya sampai jenjang SMP kelas 2 . Hal ini harus terus menjadi perhatian pemerintah daerah masing-masing dalam meningkatkan kualitas dan kuantitas layanan pendidikan di wilayahnya. Sebagaimana pendapat Becker (1994) yang menyatakan bahwa perluasan pengetahuan ilmiah dan teknis dapat meningkatkan produktivitas tenaga kerja dan masukan (input) lainnya dalam aktivitas produksi. Sehingga dengan meningkatkan nilai pendidikan dan mengadakan pelatihan kerja dapat membentuk modal manusia unggul seperti ilmuwan, teknisi, menajer, dan lain sebagainya.

b. Aspek Kesehatan

Komponen indeks pembangunan manusia selanjutnya yang digunakan untuk mewakili aspek kesehatan adalah Angka Harapan Hidup ( $\mathrm{AHH})$. Berikut adalah tabel angka rata-rata harapan hidup di Kabupaten/Kota Provinsi Kalimantan Timur selama tahun 2011-2016.

Pada Tabel 13, angka harapan hidup seluruh Kabupaten/Kota Provinsi Kalimantan Timur berada di atas rata-rata nasional yakni sebesar 70,48. Angka harapan hidup paling rendah adalah Kabupaten Penajam Paser Utara yang memiliki angka 70,50. Hal tersebut menunjukkan bahwa setiap bayi yang dilahirkan menjelang tahun 2011 akan dapat bertahan hidup hingga 70,50 tahun. Sedangkan angka harapan hidup paling tinggi adalah Kota Balikpapan dengan angka 73,94 yang menunjukkan bahwa harapan bayi yang dilahirkan menjelang tahun 2011 akan dapat hidup hingga 73,94 tahun.

Tabel 13: Angka Harapan Hidup

\begin{tabular}{|c|r|}
\hline Kabupaten Kota & \multicolumn{1}{c|}{$\begin{array}{c}\text { Angka Harapan } \\
\text { Hidup }\end{array}$} \\
\hline Pasir & 71.90 \\
\hline Kutai Barat & 71.52 .00 \\
\hline Kutai & 72.32 .00 \\
\hline Kutai Timur & 71.20 .00 \\
\hline Berau & 70.50 .00 \\
\hline Penajam Paser Utara & 73.94 \\
\hline Kota Balikpapan & 73.61 \\
\hline Kota Samarinda & 73.68 \\
\hline Kota Bontang & 70.48 .00 \\
\hline INDONESIA &
\end{tabular}

Sumber: Diolah dari Badan Pusat Statistik

Becker (1994) menyatakan bahwa adanya peningkatan layanan kesehatan atau medis senantiasa akan meningkatkan kualitas angkatan kerja yang merupakan salah satu komponen penting salam modal manusia. Hal ini juga sejalan dengan pendapat Ranis (2000) yang menyatakan bahwa ketika orang-orang menjadi lebih sehat, memiliki gizi dan pendidikan yang lebih baik, mereka akan memberikan kontribusi lebih pada pertumbuhan ekonomi yang secara tidak langsung mengarah pada peningkatan produktivitas.

c. Aspek Standar Hidup Layak

Unsur yang terakhir digunakan adalah Pengeluaran Per Kapita (PPK) untuk mewakili aspek standar hidup layak. Berikut ini adalah Tabel angka pengeluaran per kapita di seluruh daerah di Provinsi Kalimantan Timur.

Pada Tabel 14, dapat dilihat bahwa pengeluaran per kapita seluruh daerah di Provinsi Kalimantan Timur mengalami peningkatan setiap tahunnya. Rata-rata selama periode 2011-2016, menunjukkan bahwa terdapat empat daerah yang memiliki angka pengeluaran per kapita di bawah rata-rata nasional 9,965 yaitu Kabupaten Paser, Kutai Barat, Kutai Kartanegara dan Kutai Timur. Hal tersebut menunjukkan bahwa pengeluaran konsumsi penduduk selama setahun di keempat daerah masih dibawah Rp.9.965.000 per kapita. Pengeluaran perkapita paling rendah adalah Kabupaten Kutai Barat yang hanya sebesar Rp.9.616.000 per tahunnya. Berbeda halnya dengan Kota Bontang yang memiliki rata-rata pengeluaran perkapita di angka 15,738 bahkan pada tahun 2016 tercatat pengeluaran per kapita pertahunnya mencapai Rp.16.157.000. Walaupun pengeluaran per kapita berada di bawah rata-rata nasional, Kabupaten Kutai Timur memiliki rata-rata pertumbuhan pengeluaran perkapita terbesar dibandingkan dengan daerah lainnya yaitu sebesar 2,51\%, diikuti Kabupaten Paser dengan rata-rata pertumbuhan $2,18 \%$. Angka pertumbuhan tersebut jauh di atas angka rata-rata pertumbuhan nasional yang hanya berkisar di angka 1,56\%.

Tabel 14: Pengeluaran Per Kapita/ahun (dalam jutaan rupiah) 


\begin{tabular}{|c|c|c|c|c|c|c|c|}
\hline \multirow{2}{*}{ Kabupaten Kota } & \multicolumn{6}{|c|}{ Pengeluaran Per Kapita (dalam jutaan Rupiah/tahun/kapita) } \\
\cline { 2 - 8 } & $\mathbf{2 0 1 1}$ & $\mathbf{2 0 1 2}$ & $\mathbf{2 0 1 3}$ & $\mathbf{2 0 1 4}$ & $\mathbf{2 0 1 5}$ & $\mathbf{2 0 1 6}$ & Rata-Rata \\
\hline Pasir & 9,139 & 9,15 & 9,628 & 9,706 & 9,9 & 10,171 & 9,616 \\
\hline Kutai Barat & 8,746 & 8,801 & 9,228 & 9,262 & 9,38 & 9,492 & 9,152 \\
\hline Kutai Kartanegara & 9,263 & 9,281 & 9,866 & 9,984 & 10,25 & 10,593 & 9,873 \\
\hline Kutai Timur & 8,801 & 9,049 & 9,297 & 9,484 & 9,704 & 9,96 & 9,382 \\
\hline Berau & 11,002 & 11,188 & 11,375 & 11,471 & 11,572 & 11,675 & 11,38 \\
\hline Penajam Paser Utara & 10,069 & 10,199 & 10,773 & 10,807 & 10,913 & 11,019 & 10,63 \\
\hline Kota Balikpapan & 12,922 & 13,127 & 13,333 & 13,439 & 13,705 & 13,883 & 13,401 \\
\hline Kota Samarinda & 13,128 & 13,292 & 13,455 & 13,538 & 13,825 & 14,01 & 13,541 \\
\hline Kota Bontang & 15,271 & 15,318 & 15,82 & 15,878 & 15,98 & 16,157 & 15,738 \\
\hline INDONESIA & 9,647 & 9,815 & 9,858 & 9,903 & 10,15 & 10,42 & 9,965 \\
\hline
\end{tabular}

Sumber: Diolah dari Badan Pusat Statistik

Berdasarkan data tersebut, dapat dikatakan di wilayah Provinsi Kalimantan Timur masih terjadi ketimpangan distribusi pendapatan antar daerah. Hal tersebut dapat dilihat pada Tabel 15 sebagai berikut.

Tabel 15: Koefisien Gini

\begin{tabular}{|c|c|c|c|c|c|c|c|}
\hline Provinsi & $\mathbf{2 0 1 1}$ & $\mathbf{2 0 1 2}$ & $\mathbf{2 0 1 3}$ & $\mathbf{2 0 1 4}$ & $\mathbf{2 0 1 5}$ & $\mathbf{2 0 1 6}$ & Rata-Rata \\
\hline Kalimantan Timur & 00.32 & 00.36 & 00.37 & 00.36 & 00.32 & 00.33 & 00.34 \\
\hline Indonesia & 00.39 & 00.41 & 00.41 & 00.41 & 00.40 & 00.39 & 00.40 \\
\hline
\end{tabular}

Sumber: Diolah dari Badan Pusat Statistik

Pada Tabel 15, dapat dilihat bahwa koefisien gini di Provinsi Kalimantan Timur berada di atas angka 0,30 dengan rata-rata selama 6 tahun yaitu 0,34. Angka tersebut masih berada di bawah rata-rata nasional yang sebesar 0,40. Sesuai dengan kriteria kategori ketimpangan, koefisien gini di atas 0,3 sampai dengan 0,5 menunjukkan terjadinya ketimpangan sedang. Semakin rendah koefisien gini suatu wilayah maka semakin kecil pula ketimpangan distribusi pendapatan di wilayah tersebut.

\section{KESIMPULAN DAN SARAN}

Penelitian menyimpulkan bahwa variabel independen desentralisasi fiskal yang diwakili dengan derajat desentralisasi fiskal berpengaruh negatif dan tidak signifikan terhadap pertumbuhan ekonomi di Kalimantan Timur. Hal tersebut disebabkan kemungkinan adanya ketidakefisienan dan ketidakefektifan pemerintah daerah dalam mengelola desentralisasi fiskal untuk mendorong perekonomian (Martinez \& McNab, 2001). Penyebab lainnya adalah karena terjadinya penurunan ekonomi global yang ditandai dengan perlambatan perekonomian global dan melemahnya harga komoditas seperti minyak bumi dan batu bara. Penurunan perekonomian global yang terjadi sangat berdampak pada menurunnya pendapatan Provinsi Kalimantan Timur.

Selanjutnya, variabel investasi pemerintah memperoleh hasil uji bahwa investasi berpengaruh negatif dan tidak signifikan terhadap pertumbuhan ekonomi regional Kalimantan Timur. Proporsi investasi pemerintah di hampir seluruh daerah terbilang besar mencapa di atas 30 persen dari jumlah total belanja. Bahkan alokasi untuk belanja modal lebih besar dibandingkan belanja lainnya seperti belanja pegawai, belanja barang dan jasa, dan belanja sosial. Namun, proporsi yang besar tersebut belum mampu meningkatkan pertumbuhan ekonomi. Hal tersebut bisa saja terjadi disebabkan karena masih kurangnya efektitifitas pengelolaan belanja daerah sehingga belum dapat memberikan dampak langsung terhadap perekonomian (Martinez \& McNab, 2001). Selain itu, menurut Jocas (2012), investasi berpengaruh negatif terhadap pertumbuhan ekonomi disebabkan karena investasi yang tidak tepat sasaran.

Variabel indeks pembangunan manusia berpengaruh negatif dan signifikan terhadap pertumbuhan ekonomi. Ketidakselarasan perkembangan IPM yang cenderung meningkat dan pertumbuhan ekonomi yang cenderung menurun setiap tahunnya, diduga menjadi penyebab bertolak belakangnya hubungan kedua variabel tersebut. Namun, signifikansi pengaruh indeks pembangunan manusia terhadap pertumbuhan ekonomi menjadi perhatian khusus pemerintah untuk senantiasa mengembangkan kualitas manusia di wilayahnya. Tiga aspek penting bagi pembangunan manusia yakni pendidikan, kesehatan, dan standar hidup layak. Peningkatan kualitas dari ketiga aspek tersebut diharapkan dapat mempengaruhi peningkatan pertumbuhan ekonomi regional di Provinsi Kalimantan Timur.

Penulis berharap pemerintah daerah dapat terus menggali potensi pendapatan lain diluar pendapatan komoditas sumber daya alam seperti sektor pariwisata, industri, komunikasi, maupun sektor lainnya yang dapat menunjang peningkatan pendapatan asli daerah Kalimantan Timur. Selain itu peningkatan kualitas layanan kesehatan, pendidikan, dan peningkatan standar hidup layak menjadi hal penting yang harus menjadi fokus pemerintah guna mencapai keberhasilan pembangunan dan ekonomi serta kesejahteraan masyakat. Dengan pengelolaan keuangan yang baik, dirapkan anggaran Pemerintah Daerah dapat menunjang pembangunan, baik pembangunan manusia maupun pembangunan fisik yang akhirnya dapat meningkatkan pertumbuhan ekonomi daerah dan menghindari adanya temuan-temuan atas ketidakefisienan dan ketidakbenaran pengelolaan keuangan daerah (Dinarjito, 2017).

Bagi penelitian selanjutnya, penulis menyarankan penelitian selanjutnya dapat menggunakan metode penelitian yang berbeda dan pendekatan yang berbeda untuk menjelaskan atau mengungkapkan fenomena yang terjadi atau dengan menambah variabel yang lain untuk dapat menjelaskan dengan lengkap variabel yang mempengaruhi pertumbuhan ekonomi.

\section{IMPLIKASI DAN KETERBATASAN}

Dalam melakukan sebuah penelitian, pasti akan selalu ada suatu kelemahan atau keterbatasan. Penulis menyadari bahwa penelitian ini memiliki beberapa 
keterbatas antara lain: keterbatasan periode penelitian yang hanya menggunakan periode selama 6 tahun yaitu tahun 2011 hingga 2016, keterbatasan jumlah variabel yang digunakan dalam penelitian ini yang juga dikarenakan adanya keterbatasan data yang dapat diperoleh penulis, dan terakhir keterbatasan metode penelitian yang hanya menggunakan regresi berganda data panel. Penelitian ini akan lebih bagus apabila menggunakan metode lain yang lebih representatif dalam menghasilkan simpulan penelitian.

\section{DAFTAR PUSTAKA (REFERENCES)}

Amagoh, F., \& Ajab Amin, A. (2012). An Examination of the Impacts of Fiscal Decentralization on Economic Growth. International Journal of Business Administration. https://doi.org/10.5430/ijba.v3n6p72

Arsyad, L. (1999). Pengantar Perencanaan dan Pembangunan Ekonomi Daerah (Pertama). Yogyakarta: Penerbit BPFE.

Badan Pusat Statistik - Direktorat Analisis dan Pengembangan Statistik. (2015). Indeks Pembangunan Manusia. Retrieved March 11, 2018, from http://ipm.bps.go.id/page/ipm

Bado, B. (2015). Analisis Belanja Modal, Investasi, dan Tenaga Kerja Terhadap Pertumbuhan Ekonomi Sulawesi Selatan (Capital Expendituress Analysis, Investment, and Employment on Economic Growth South Sulawesi). Econosains Jurnal Online Ekonomi Dan Pendidikan. https://doi.org/10.21009/econosains.0132.03

Bahl, R. W. \& Linh, J. (1992). Urban Finance in Development Countries. New York.

Bati. (2009). Pengaruh Belanja Modal dan Pendapatan Asli Daerah (PAD) Terhadap Pertumbuhan Ekonomi (Studi Kabupaten dan Kota di Sumatera Utara). Medan.

Becker, G. S. (1994). Human Capital: A Theoretical and Empirical Analysis with Special Reference to Education (3rd Editio, pp. 15-28). Chicago: The University of Chicago Press.

Bird, R. . (1993). Threading the Fiscal Labyrinth: Some Issues in Fiscal Decentralization. National Tax Journal, 46(3), 207-277.

Davoodi, H., \& Zou, H. F. (1998). Fiscal Decentralization and Economic Growth: A Cross-Country Study. Journal of Urban Economics. https://doi.org/10.1006/juec.1997.2042

Dinarjito, A. (2017). Analisis Temuan Badan Pemeriksa Keuangan Atas Penerimaan Negara Bukan Pajak Kementerian/Lembaga. Info Artha, 1(1), 1. https://doi.org/10.31092/jia.v1i1.5

Dwirandra, A. A. N. B. (2013). Pengaruh Desentralisasi Fiskal Pada Pertumbuhan Ekonomi Dengan Keserasian Belanja Daerah Sebagai Variabel
Pemoderasi. Jurnal IImiah Akuntansi Dan Bisnis, 8(2), 66-74.

Handayani, T. (2011). Faktor-faktor yang Mempengaruhi Pertumbuhan Ekonomi di Indonesia Periode 1999-2008. Yogyakarta.

Jocas, M. (2012). Pengaruh Investasi, Jumlah Tenaga Kerja dan Pengeluaran Pemerintah Terhadap Pertumbuhan Ekonomi di Timor Leste Periode 2004-2011. Yogyakarta.

Jumadi, M. Pudjiharjo, G. M. dan M. K. (2013). The Impact of Fiscal Decentralization on Local Economic Development in East Java. IOSR Journal Of Humanities And Social Science (IOSR-JHSS), 13(1), 1-7.

Jumadi, M. P., Maski, G., \& Khusaini, M. (2013). The Impact of Fiscal Decentralization on Local Economic Development in East Java. IOSR Journal Of Humanities And Social Science (IOSR-JHSS), 13(1), 1-7.

Kharisma, B. (2013). Desentralisasi Fiskal dan Pertumbuhan Ekonomi: Sebelum dan Sesudah Era Desentralisasi Fiskal di Indonesia. Jurnal Ekonomi Dan Studi Pembangunan, 14(2), 101119.

Lin, J. Y., \& Liu, Z. (2000). Fiscal Decentralization and Economic Growth in China. Economic Development and Cultural Change, 49(1), 1-21.

Martinez, V. J. M., \& McNab, R. (2001). Fiscal decentralization, Economic Growth, and Democratic Governance.

Meier, G. M. (1989). Leading Issues Economic Development (5th Editio). New York: Oxford University Press.

Muqorrobin, M., \& Soejoto, A. (2017). Pengaruh Indeks Pembangunan Manusia Terhadap Pertumbuhan Ekonomi Provinsi Jawa Timur. Jurnal Pendidikan Ekonomi, 5(3).

Nanga, M. (2005). Makro Ekonomi: Teori, Masalah dan Kebijakan. Jakarta: PT. Raja Grafindo Persada.

Nurmainah, S. (2013). Analisis Pengaruh Belanja Modal Pemerintah Daerah, Tenaga Kerja Terserap, dan Indeks Pembangunan Manusia Terhadap Pertumbuhan Ekonomi dan Kemiskinan. Jurnal Bisnis Dan Ekonomi (JBE), 20(2), 131-141.

Oates, W. E. (1993). Fiscal Decentralization and Economic Development. National Tax Journal, 26(2), 237-243.

Phillips, K. L., \& Woller, G. (1997). Does Fiscal Decentralization Lead to Economic Growth?

Ranis, G. (2000). Economic Growth and Human Development. Jurnal World Development, 28(2), 197-219.

Saputra, B., \& Mahmudi. (2012). Pengaruh Desentralisasi Fiskal Terhadap Pertumbuhan Ekonomi dan Kesejahteraan Masyarakat. Jurnal Akuntansi Dan Audit Indonesia (JAAI), 16(2), 185- 
199.

Saragih, J. P. (2003). Desentralisasi Fiskal dan Keuangan Daerah dalam Otonomi. Bogor: Penerbit Ghalia Indonesia.

Satria, A. B. (2016). Pengaruh Derajat Desentralisasi Fiskal Terhadap Pertumbuhan Ekonomi Kabupaten/Kota Provinsi Jawa Timur Tahun 2004-2013. Surabaya.

Simanjuntak, P. (2005). Pengantar IImu Ekonomi Sumber Daya Manusia. Jakarta: LPFE UI.

Situngkir, F., Sirojuzilam, E., \& Suriadi, A. (2014). Pengaruh Desentralisasi Fiskal Terhadap Pertumbuhan Ekonomi di Provinsi Sumatera Utara. Jurnal Ekonom, 17(3), 125-137.

Sugiyono. (2009). Metode Penelitian Kuantitatif, Kualitatif, dan R\&D. Bandung: CV Alfabeta.

Sukirno, S. (2011). Makro Ekonomi Teori Pengantar (3rd ed.). Jakarta: Rajawali Pers.

Sulistiawati, R. (2012). Pengaruh Investasi Terhadap Pertumbuhan Ekonomi dan Penyerapan Tenaga Kerja Serta Kesejahteraan Masyarakat di Provinsi di Indonesia. Jurnal Ekonomi Bisnis Dan Kewirausahaan, 3(1), 29-50.

Sutawijaya, A. (2010). Pengaruh Ekspor dan Investasi terhadap Pertumbuhan Ekonomi Indonesia tahun 1980-2006. Jurnal Organisasi Dan Manajemen.

Todaro, Michael P. \& Smith, S. C. (2006). Pembangunan Ekonomi. (H. Munandar \& P. A.L, Eds.) (Edisi $9 \mathrm{Ji}$ ). Jakarta: Erlangga.

Todaro, M. P. (2005). Economic Development in the Third World. New York: Longman.

World Bank. (1997). The World development Report. New York.

Zhang, T., \& Zou, H. (2001). The Growth Impact of Intersectoral and Intergovermental Allocation of Public Expenditure: With Application in China and India. China Economics. 